\title{
Effect of variable heat input on the heat transfer characteristics in an Organic Rankine Cycle system
}

\author{
Mahdi Hatf Kadhum Aboaltabooq ${ }^{1, *}$, Tudor Prisecaru ${ }^{2}$, Horatiu Pop ${ }^{2}$, Valentin Apostol ${ }^{2}$, Malina Prisecaru², \\ Gheorghe Popescu ${ }^{2}$, Elena Pop ${ }^{2}$, Ana-Maria Alexandru², Cristian Petcu ${ }^{3}$, and Cristina Ciobanu ${ }^{2}$ \\ ${ }^{1}$ University POLITEHNICA of Bucharest, Splaiul Independentei 313, Bucharest 060042, Romania \\ 2 Splaiul Independent ei 313, Bucharest 060042, Romania \\ 3 Rokura Company, Rahmaninov Street, Nr. 46-48, Bucharest, Romania
}

\begin{abstract}
This paper analyzes the heat transfer characteristics of an ORC evaporator applied on a diesel engine using measured data from experimental work such as flue gas mass flow rate and flue gas temperature. A mathematical model was developed with regard to the preheater, boiler and the superheater zones of a counter flow evaporator. Each of these zones has been subdivided into a number of cells. The hot source of the ORC cycle was modeled. The study involves the variable heat input's dependence on the ORC system's heat transfer characteristics, with especial emphasis on the evaporator. The results show that the refrigerant's heat transfer coefficient has a higher value for a $100 \%$ load from the diesel engine, and decreases with the load decrease. Also, on the exhaust gas side, the heat transfer coefficient decreases with the decrease of the load. The refrigerant's heat transfer coefficient increased normally with the evaporator's tube length in the preheater zone, and then increases rapidly in the boiler zone, followed by a decrease in the superheater zone. The exhaust gases' heat transfer coefficient increased with the evaporator' tube length in all zones. The results were compared with result by other authors and were found to be in agreement.
\end{abstract}

\section{Introduction}

One of the methods to improve the thermal efficiency of an internal combustion engine is the usage of Organic Rankine Cycle systems (ORCs) to recover waste heat. The available heat which, is called waste heat, is transferred to the organic working fluid by means of an evaporator in an ORC, where the organic working fluid changes from a liquid state to a vapor state under a high pressure. Then, the organic working fluid, which has a high enthalpy, is expanded in an expander, and output power is generated.

Since the ORC systems generate additional power without requiring extra fuel, the specific pollutant emissions of the combined plant are reduced.

Engine waste energy is transferred to the organic working fluid by means of an evaporator in an ORC, so the evaporator is an important part of the ORC for an engine waste-heat recovery system. Many studies analyzing ORC performances have been conducted recently [1-7]. Most of these studies have dealt with heat source as a stable source for simplicity. A few studies have dealt with variable heat sources.

Therefore, this study has addressed the variable heat source effect on counter-flow evaporator characteristics. The working fluid R245fa was selected as the working fluid. A mathematical model of the evaporator is developed

\footnotetext{
* e-mail: hatfmahdi@yahoo.com
}

according to the detailed dimensions of the designed evaporator and the specified ORC working conditions. Finally the model focuses on the influence of the heat source from an internal combustion engine, according to the operation of engine (50-100\%) load on the heat transfer characteristics in the Organic Rankine Cycle (ORC).

\section{Mathematical model}

The thermodynamic processes in the ORC system as shown in Figure 1 - it starts from (1-2) pump process, followed by $(2-3)$ the heat addition process (across the evaporator), the expansion process (3-4) (across the turbine). Before the working fluid returns to point (1) it passes through the condenser process $(4-1)$.

In this study, the evaporator was divided into three main zones - preheater, boiler and superheater - as shown in Figure 2. This division is not sufficient to determine the heat transfer coefficient, the properties of the evaporator, and so on. Therefore, each evaporator zone was divided into a number of volumes as follows:

- The preheater zone was divided into 60 nodes or $\left(N_{\mathrm{pr}}-1\right)$ volumes.

- The boiler zone was divided into 10 nodes or $\left(N_{\mathrm{b}}-1\right)$ volumes.

- The superheater zone was divided into 11 nodes or $\left(N_{\mathrm{sp}}-1\right)$ volumes. 


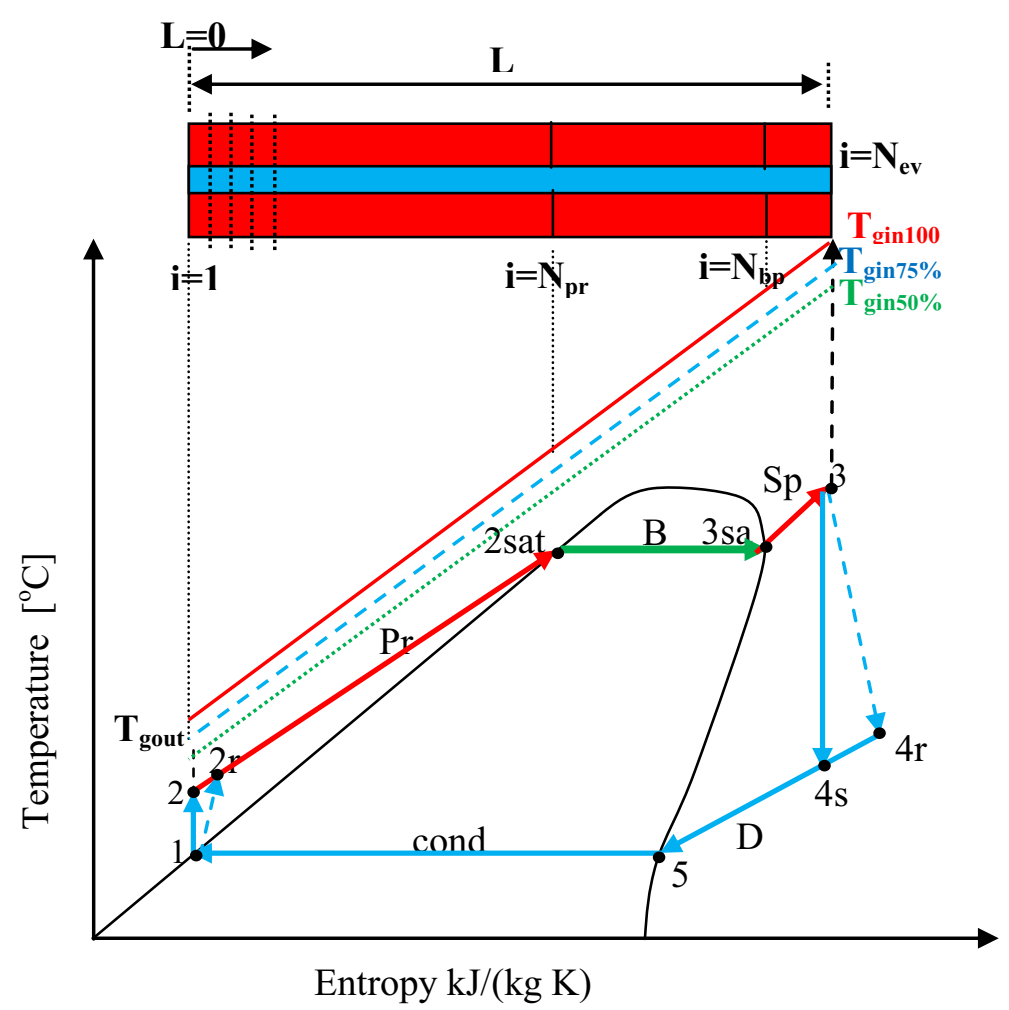

Fig. 1. T-S diagram of the ORC system.

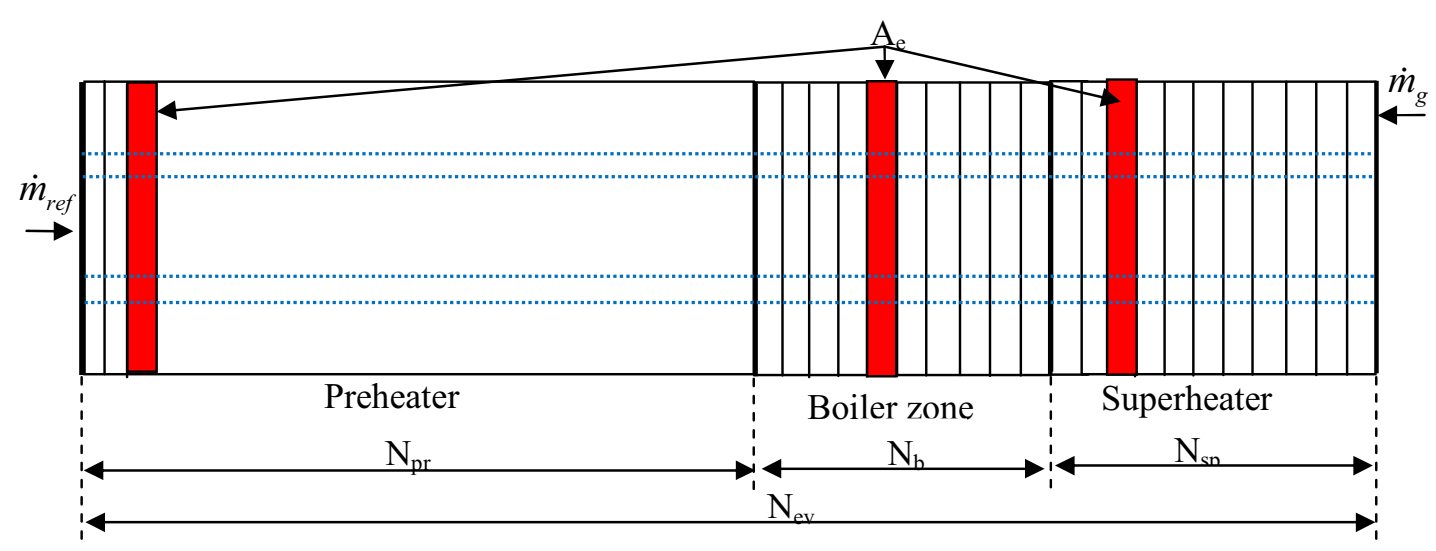

Fig. 2. Evaporator division representation.

For each volume, a heat exchange area is defined as:

$$
A_{e}=\frac{A_{\mathrm{pr}}}{N_{\mathrm{pr}}-1}=\frac{A_{\mathrm{br}}}{N_{b}-1}=\frac{A_{\mathrm{sp}}}{N_{\mathrm{sp}}-1}
$$

which:

$$
N_{\mathrm{ev}}=N_{\mathrm{pr}}+N_{b}+N_{\mathrm{sp}}
$$

$A_{\mathrm{e}}$ is the element area; $N_{\mathrm{pr}}$ is the number of nodes in the preheater, $N_{\mathrm{b}}$ is the number of nodes in the boiler zone, $N_{\mathrm{sp}}$ is the number of nodes in the superheater zone.

$N_{\mathrm{ev}}$ is the number of nodes in all the evaporator zones.
The evaporator area is equal to the sum of the preheater, boiler and superheater zones. For each evaporator zone there are two sides; refrigerant side and exhaust gas side. Table 1 shows the evaporator model parameters from design. In order to determine the heat transfer coefficients for each zone and for each side we can see the reference [9]. by:

The total power input to the engine $\left(P_{\text {tot }}\right)$ is determined

$$
P_{\text {tot }}=\dot{m}_{\text {fuel }} \mathrm{LHV} .
$$

The engine's mechanical efficiency of $\left(\eta_{\text {eng }}\right)$ is calculated by:

$$
\eta_{\mathrm{eng}}=\left(\frac{P_{\mathrm{eng}}}{P_{\mathrm{tot}}}\right) \times 100 .
$$


Table 1. Evaporator model parameters from design [8].

\begin{tabular}{llll}
\hline Parameter & Symbol & Value & Unit \\
\hline Evaporator area & $A_{\mathrm{ev}}$ & 2.215 & $\mathrm{~m}^{2}$ \\
Preheater area & $A_{\mathrm{pr}}$ & 1.6756 & $\mathrm{~m}^{2}$ \\
Boiler area & $A_{\mathrm{b}}$ & 0.2556 & $\mathrm{~m}^{2}$ \\
Superheater area & $A_{\mathrm{sp}}$ & 0.284 & $\mathrm{~m}^{2}$ \\
Total length of evaporator & $\mathrm{Le}_{\mathrm{tot}}$ & $\mathrm{m}$ \\
Preheater length & $L_{\mathrm{pr}}$ & 17.62 & $\mathrm{~m}$ \\
Boiler length & $L_{\mathrm{b}}$ & 13.33 & $\mathrm{~m}$ \\
Superheater length & $L_{\mathrm{sp}}$ & 2.034 & $\mathrm{~m}$ \\
Outside diameter of the outer tube & $d$ & 2.26 & $\mathrm{~m}$ \\
Outside diameter of the inner tube & $\mathrm{do}$ & 0.06 & $\mathrm{~m}$ \\
Inside diameter of the inner tube & $\mathrm{di}$ & 0.04 & $\mathrm{~m}$ \\
\hline
\end{tabular}

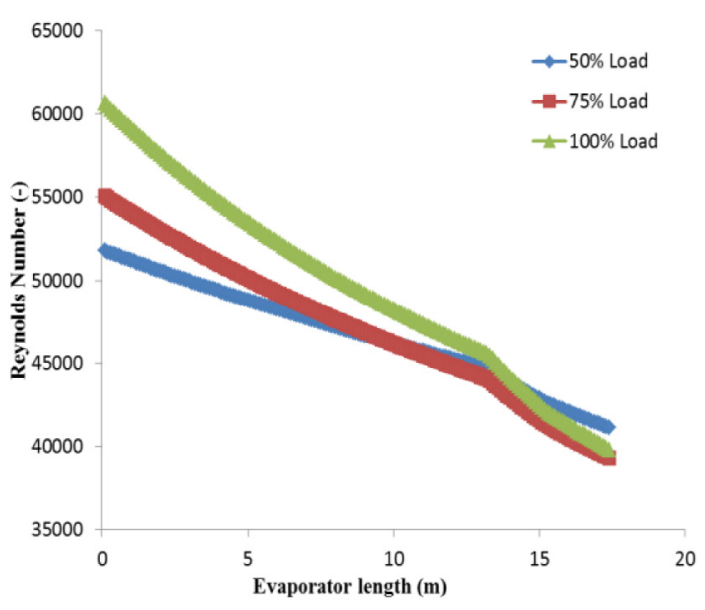

Fig. 3. Reynolds number of exhaust gas.

The engine's mechanical efficiency combined with ORC $\left(\eta_{\text {eng,ORC }}\right)$ is calculated by:

$$
\eta_{\mathrm{eng}, \mathrm{ORC}}=\left(\frac{P_{\mathrm{eng}}+W_{\mathrm{net}}}{P_{\mathrm{tot}}}\right) \times 100 .
$$

The fuel reduction percentage (FRP) is calculated by:

$$
\mathrm{FRP}=\left(1-\frac{\eta_{\mathrm{eng}}}{\eta_{\mathrm{eng}, \mathrm{ORC}}}\right) \times 100 .
$$

Where LHV is the lower heating value for fuel, $P_{\text {eng }}$ is engine power, $\dot{m}_{\text {fuel }}$ is the mass flow rate of fuel, $W_{\text {net }}$ is the work net for ORC.

\section{Results}

Based on the mathematical model, a program has been developed in the software Engineering Equation Solver (EES) [10]. The results are presented in Figures 3-6. From Figures 3 and 4 it can be observed that the Reynolds number of exhaust gas decreases with tube length and that the exhaust gas heat transfer coefficient increases with tube length, respectively.

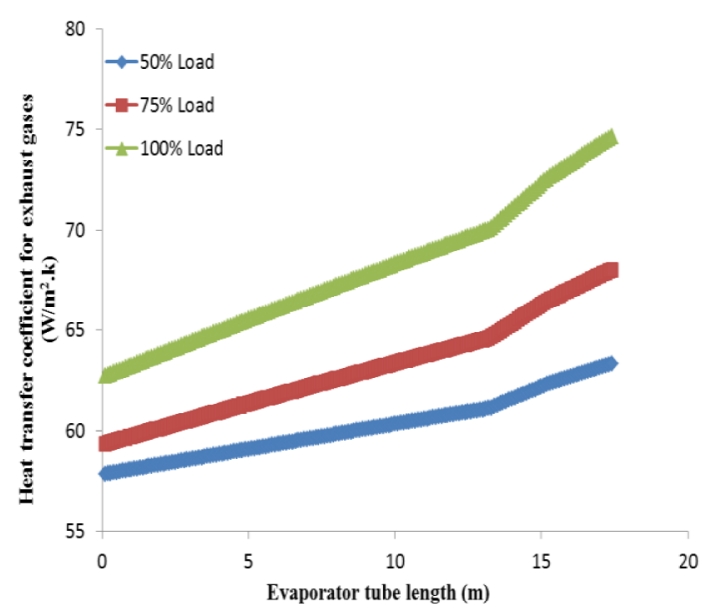

Fig. 4. Heat transfer coefficient of exhaust gas.

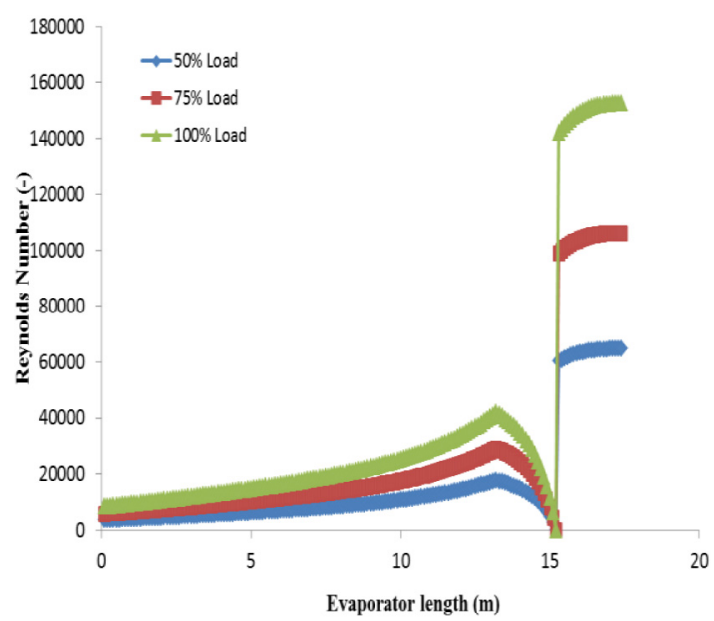

Fig. 5. Reynolds number of refrigerant.

Figure 5 shows that the refrigerant's Reynolds number increases in the preheater zone and decreases in the boiler zone, and returns to an increase in the superheater zone. Figure 6 shows that the heat transfer coefficient of 


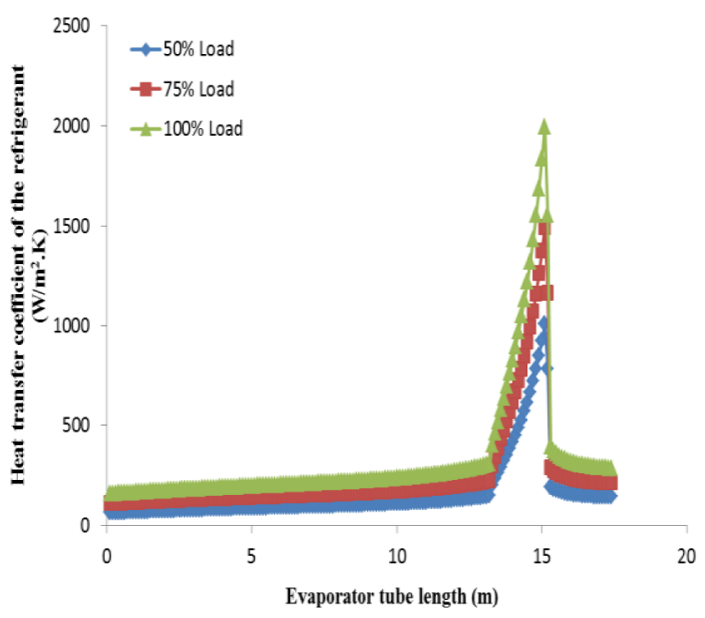

Fig. 6. Heat transfer coefficient of refrigerant.

refrigerant with tube length in the preheater zone increases, then increases suddenly in the boiler zone. Finally, in the superheater zone, the heat transfer coefficient decreases with tube length.

Table 2 shows the load variations on ORC performance for R245fa as a working fluid.
The comparison shows a very good agreement between present results and the results in the references [11] and [12], as shown in Table 3.

\section{Conclusions}

This paper studied the performance of the evaporator with preheated, boiler and superheater zone. After obtaining the diesel engine exhaust thermal characteristics from the experimental data, the evaporator's mathematical model is built according to the ORC specific working conditions and the evaporator's geometrical parameters. Three typical engine operating conditions are used to estimate the evaporator's heat transfer characteristics. The result shows that, in the evaporator, the working fluid's heat transfer coefficient is much higher than the exhaust side of the engine. The boiler zone's heat transfer rate is higher than the preheater and superheater zones. The fuel reduction percentage for $100 \%$ load is $6.048 \%$ and for $75 \%$ load is $4.294 \%$, but for $50 \%$ load it is $2.659 \%$.

One of the authors (M.H.K. Aboaltabooq) acknowledges support from the Ministry of Higher Education and Scientific Research of Iraq through grant and the Romanian Government through

Table 2. Effect of load variations on ORC performance.

\begin{tabular}{|c|c|c|c|c|c|}
\hline Parameter & Symbol & $100 \%$ & $75 \%$ & $50 \%$ & Units \\
\hline Type of working fluid & $\mathrm{R} \$$ & $\mathrm{R} 245 \mathrm{fa}$ & $\mathrm{R} 245 \mathrm{fa}$ & $\mathrm{R} 245 \mathrm{fa}$ & - \\
\hline Source temperature & $\mathrm{Tg}_{\mathrm{in}}$ & 477 & 407 & 327 & $\mathrm{C}$ \\
\hline Source mass flow rate & $\dot{m}_{g}$ & 0.053 & 0.049 & 0.047 & $\mathrm{~kg} / \mathrm{s}$ \\
\hline Refrigerant mass flow rate & $\dot{m}_{\mathrm{ref}}$ & 0.066 & 0.046 & 0.028 & $\mathrm{~kg} / \mathrm{s}$ \\
\hline Superheater temperature difference & $\Delta T_{\text {sup }}$ & 30 & 30 & 30 & $\mathrm{C}$ \\
\hline Evaporation pressure & $P_{\mathrm{ev}}$ & 32.57 & 32.57 & 32.57 & bar \\
\hline Inlet turbine temperature & $T_{3}$ & 175 & 175 & 175 & $\mathrm{C}$ \\
\hline Heat rate input & $\dot{Q}_{\text {add }}$ & 20.11 & 14.01 & 8.53 & $\mathrm{~kW}$ \\
\hline Net work & $W_{\text {net }}$ & 2.427 & 1.692 & 1.03 & $\mathrm{~kW}$ \\
\hline Thermal efficiency & $\eta_{\text {th }}$ & 12.07 & 12.07 & 12.07 & $\%$ \\
\hline Fuel reduction percentage & FRP & 6.048 & 4.294 & 2.659 & $\%$ \\
\hline Lower heating value of fuel & HLV & 43,000 & 43,000 & 43,000 & $\mathrm{~kJ} / \mathrm{kg}$ \\
\hline Net output power of the engine & $P_{\text {eng }}$ & 37.7 & 28.27 & 18.85 & $\mathrm{~kW}$ \\
\hline
\end{tabular}

Table 3. Validation of the numerical model with the previously published data $[11,12]$.

\begin{tabular}{llllllllll}
\hline $\begin{array}{l}\text { Parameter } \\
\text { Unit }\end{array}$ & $\begin{array}{l}P_{\text {ORC }} \\
\mathrm{kW}\end{array}$ & $\begin{array}{l}\eta_{\text {ORC }} \\
\%\end{array}$ & $\begin{array}{l}P_{\text {con }} \\
\mathrm{kPa}\end{array}$ & $\begin{array}{l}P_{\text {ev }} \\
\mathrm{kPa}\end{array}$ & $\begin{array}{l}T_{\text {ev }} \\
\mathrm{K}\end{array}$ & $\begin{array}{l}\dot{m}_{\text {ref }} \\
\mathrm{kg} / \mathrm{s}\end{array}$ & $v_{4} / v_{3}$ & $\begin{array}{l}\Delta h_{3-4} \\
\mathrm{~kJ} / \mathrm{kg}\end{array}$ & Ref. \\
\hline R11 & 273.7 & 15.9 & 14.72 & 3835.9 & 461.5 & 7.475 & 31.95 & 42.21 & 11 \\
$\mathrm{R} 11$ & 290.3 & 16.58 & 14.79 & 3835.9 & 461 & 7.487 & 32 & 41.9 & 12 \\
R11 & 274.9 & 15.97 & 14.79 & 3835 & 461.45 & 7.39 & 28.07 & 42.73 & Present \\
R134a & 145.9 & 8.47 & 883.8 & 3723.4 & 369.9 & 9 & 5.263 & 19.2 & 11 \\
R134a & 147.5 & 8.52 & 883.3 & 3723.4 & 369.9 & 8.966 & 5 & 19.4 & 12 \\
R134a & 147.1 & 8.548 & 887.5 & 3723 & 369.9 & 8.814 & 4.9 & 19.71 & Present \\
\hline
\end{tabular}


Research grant, "Hybrid micro-cogeneration group of high efficiency equipped with an electronically assisted ORC", 1st Phase Report, 2nd National Plan, Grant Code: PN-II-PT-PCCA2011-3.2-0059, Grant No.: 75/2012.

\section{References}

1. S.H. Kang, Design and experimental study of ORC (organic Rankine cycle) and radial turbine using R245fa working fluid, Energy 41, 514 (2012)

2. C. He, C. Liu, H. Gao, H. Xie, Y. Li, S. Wu, et al., The optimal evaporation temperature and working fluids for subcritical organic Rankine cycle, Energy 38, 136 (2012)

3. J. Sun, W. Li, Operation optimization of an organic Rankine cycle (ORC) heat recovery power plant, Appl. Therm. Eng. 31, 2032 (2011)

4. E.H. Wang, H.G. Zhang, B.Y. Fan, M.G. Ouyang, Y. Zhao, Q.H. Mu, Study of working fluid selection of organic Rankine cycle (ORC) for engine waste heat recovery, Energy 36, 3406 (2011)

5. A. Rentizelas, S. Karellas, E. Kakaras, I. Tatsiopoulos, Comparative technoeconomic analysis of ORC and gasification for bioenergy applications, Energy Convers. Manage. 50, 674 (2009)
6. D. Gewald, S. Karellas, A. Schuster, H. Spliethoff, Integrated system approach for increase of engine combined cycle efficiency, Energy Convers. Manage. 60, 36 (2012)

7. F. Vélez, F. Chejne, G. Antolin, A. Quijano, Theoretical analysis of a transcritical power cycle for power generation from waste energy at low temperature heat source, Energy Convers. Manage. 60, 188 (2012)

8. M.H. Kadhum, et al., Parametric investigation study of counter-flow evaporator for waste heat recovery, in $3 r d$ International Conference on Thermal Equipment, Renewable Energy and Rural Development (2014), p. 71

9. M.H. Kadhum, et al., Optimum operation conditions and behavior of organic Rankine cycle system under variable heat input with control on refrigerant mass flow rate, in 3rd report for thesis (2014)

10. http://www.mhhe.com/engcs/mech/ees/whatisees.html

11. G. Shu, L. Liu, H. Tian, H. Wei, G. Yu, Parametric and working fluid analysis of a dual-loop organic Rankine cycle (DORC) used in engine waste heat recovery, Appl. Energy 113, 1188 (2014)

12. I. Vaja, A. Gambarotta, Internal combustion engine (ICE) bottoming with organic Rankine cycles (ORCs), Energy 35, 1084 (2010)

Cite this article as: Mahdi Hatf Kadhum Aboaltabooq, Tudor Prisecaru, Horatiu Pop, Valentin Apostol, Malina Prisecaru, Gheorghe Popescu, Elena Pop, Ana-Maria Alexandru, Cristian Petcu, Cristina Ciobanu, Effect of variable heat input on the heat transfer characteristics in an Organic Rankine Cycle system, Renew. Energy Environ. Sustain. 1, 13 (2016) 